\title{
The Effect of STAF Score and Clinical Data on Paroxysmal Atrial Fibrillation Determination in Patients with Cryptogenic Stroke
} Kriptojenik İnme Hastalarında STAF Skorunun ve Klinik Verilerin Paroksismal Atriyal Fibrilasyon Saptanmasina Etkisi

\author{
(1) Aygül Tantik Pak, (1) Zahide Mail Gürkan, (1) Yıldızhan Şengül \\ Gaziosmanpasa Training and Research Hospital, Clinic of Neurology, Istanbul, Turkey
}

\begin{abstract}
Objective: To determine factors that affect paroxysmal atrial fibrillation (PAF) detection. In this regard, we evaluated the relationship between clinical and demographic data, score for the targeting of atrial fibrillation (STAF) score, CHA2DS2-VASc score, and the detection of PAF in patients with cryptogenic ischemic stroke (CIS).

Materials and Methods: This retrospective study included 98 patients who underwent 24-hour Holter electrocardiography (ECG) among 310 patients admitted to the neurology department with a diagnosis of CIS between January 2017 and July 2019. PAF was detected in Holter ECG in 49 patients. STAF score, CHA2DS2-VASc score, and demographic and clinical data were compared between patients with and without PAF.

Results: Ninety-eight patients with CIS were included in our study. The mean age of the patients was $64.4 \pm 14.1$ years. Of the patients included in the study, $50 \%(\mathrm{n}=49)$ were in the group with PAF and 50\% $(\mathrm{n}=49)$ were in the group without PAF. The comparison of age between patients with and without PAF was statistically significant $(66.98 \pm 11.9$ and $59.84 \pm 15.23$, respectively; $\mathrm{p}=0.01)$. Sex, additional risk factors, presence of vascular disease, recurrent stroke, CHA2DS2VASc score, left atrial dilatation, left ventricular hypertrophy, mitral insufficiency, STAF score, National Institutes of Health Stroke Scale Score, and modified Rankin Scale were not significantly associated with PAF ( $>0.05$ )

Conclusion: PAF should be investigated in strokes of unknown etiology in the elderly population. However, this study shows that STAF and CHA2DS2-VASc score, transthoracic echocardiography findings, and other risk factors are not associated with PAF detection. Future studies with longer Holter ECG recordings in larger samples will shed light on this issue.
\end{abstract}

Keywords: Paroxysmal atrial fibrillation, cryptogenic ischemic stroke, CHA2DS2-VASc score, STAF score

$\ddot{O} \mathbf{z}$

Amaç: Paroksismal atriyal fibrilasyon (PAF) saptanmasını etkileyen faktörleri belirlemeyi amaçladık. Bu nedenle kriptojenik iskemik inme (KİI) geçiren hastalarda klinik ve demografik verilerin, score for the targeting of atrial fibrillation (STAF) ve CHA2DS2-VASc skorunun, PAF saptanması ile ilişkisini değerlendirdik.

Gereç ve Yöntem: Retrospektif olarak yapılan bu çalışmaya Ocak 2017 ile Temmuz 2019 tarihi arasında KIİ tanısı ile nöroloji servisine yatırılan 310 hastadan kliniğimizde 24 saatlik Holter elektrokardiyografi (EKG) çekilen 98 hasta dahil edilmiştir. Hastaların 49'unda Holter EKG'de PAF saptanmış ve 49'unda PAF saptanmamıştır. PAF saptanan ve saptanmayan hastalar arasındaki STAF skoru, CHA2DS2-VASc skoru, demografik ve klinik veriler karşılaştırılmıştır.

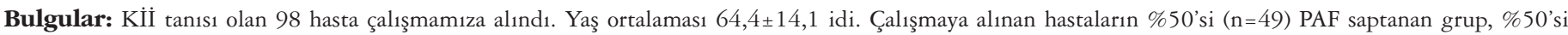
( $\mathrm{n}=49)$ PAF saptanmayan gruptu. PAF saptanan ve saptanmayan grupta yaşın karşılaştırması istatistiksel olarak anlamlıydı (PAF saptananlar: 66,98 $\pm 11,9, \mathrm{PAF}$ saptanmayanlar $=59,84 \pm 15,23, \mathrm{p}=0,01)$. Cinsiyet, konjestif kalp yetmezliği, diabetes mellitus, hipertansiyon, vasküler hastalı $\breve{g} 1 n$ olmasının, tekrarlayan inme, CHA2DS2-VASc skoru, sol atriyal dilatasyon, sol ventrikül hipertrofisi, mitral yetmezlik, STAF skoru, National Institutes of Health Stroke Scale ve Prestrok modifiye Rankin Skalası ile PAF saptanması arasındaki ilişki anlamlı bulunmadı ( $\mathrm{p}>0,05$ ).

Sonuç: İleri yaş popülasyonda nedeni bilinmeyen inmelerde mutlaka PAF aranmalıdır. Fakat bu çalışma gösteriyor ki STAF ve CHA2DS2-VASc skoru, transtorasik ekokardiyografi bulguları ve diğer risk faktörleri PAF saptanması ile ilişkili değildir. Gelecekteki daha fazla örneklem grubuyla daha uzun holter EKG kaydı kullanılarak yapılacak çalışmalar bu konuya ışık tutacaktır.

Anahtar Kelimeler: Paroksismal atriyal fibrilasyon, kriptojenik inme, CHA2DS2-VASc skoru, STAF skoru

Address for Correspondence/Yazışma Adresi: Aygül Tantik Pak MD, Gaziosmanpasa Training and Research Hospital, Clinic of Neurology, Istanbul, Turkey Phone: +90 5072420419 E-mail: aa.aygultantik@hotmail.com ORCID: orcid.org/0000-0002-7414-3800

Received/Geliş Tarihi: 28.12.2019 Accepted/Kabul Tarihi: 18.02 .2020

${ }^{\circ}$ Copyright 2020 by Turkish Neurological Society

Turkish Journal of Neurology published by Galenos Publishing House. 


\section{Introduction}

Stroke is the second highest cause of death after myocardial infarction in the world, and it is also a disease that causes disability and impairment in quality of life. Therefore, determining the etiology of stroke and planning prophylactic treatment is very important in preventing recurrent strokes, which increase disability and even result in death. Ischemic strokes constitute $80 \%$ of strokes. An etiology cannot be found in approximately one-quarter of ischemic strokes and this is defined as cryptogenic ischemic stroke (CIS) (1). The Trial of Org 10172 in Acute Stroke Treatment classification is widely used in stroke classification. In this classification, stroke etiology is classified as large vessel disease, cardioembolic stroke, small vessel disease, and other causes and causes of unknown origin (2). The stroke group for which a specific etiology cannot be found with extensive research is called CIS. However, many different classifications are used and the lack of consensus on this issue explains the reported variable rates of CIS (3). Atrial fibrillation (AF) is a widely known risk factor in the etiology of ischemic stroke. AF may be chronic or paroxysmal (4). Paroxysmal AF (PAF) constitutes $25-62 \%$ of patients with AF (5). PAF is found as an etiologic factor in approximately $11-30 \%$ of the patients with CIS (6). The risk of stroke in those with PAF in Holter electrocardiography (ECG) is twice as high as in those without PAF (7). PAF is a cardiac arrhythmia that recurs at different durations and ends spontaneously, sometimes as a single attack, sometimes in successive clusters. Failure to detect PAF due to its self-terminating nature causes inadequate diagnosis and incorrect treatment (8). Ischemic strokes caused by both paroxysmal and chronic AF can be successfully prevented by oral anticoagulation (9). Therefore, the recognition of AF and effective anticoagulation is extremely important in patients with ischemic stroke.

In our study, it was planned to find factors that affect the detection of PAF by comparing the Score for the Targeting of AF (STAF) score, which is used to predict PAF, the CHA2DS2-VASc score, which is used to determine the risk of thromboembolism in patients with AF, and demographic and clinical data between patients with and without PAF. It was planned to determine the effect of PAF detection on clinical outcomes by comparing the National Institutes of Health Stroke Scale Score (NIHSS) and the modified Rankin scale (mRS) score calculated in the first and last examinations, between the two groups.

\section{Materials and Methods}

This study was approved by the Taksim Research and Training Hospital Ethics Committee (number: 102, date: 21.08.2019). The study complied with the Helsinki Declaration criteria. Of 310 patients who were admitted to the neurology ward with a diagnosis of CIS between January 2017 and July 2019, 98 patients who had 24-hour rhythm Holter ECG in our clinic were included in the study. The remaining patients were excluded from the study because their Holter ECG recordings were not performed in our hospital or they were not followed up. PAF was detected in the Holter ECG in 49 of 98 patients included in the study, and PAF was not detected in 49 of them. Written or verbal consent was not obtained from the patients because the study was conducted retrospectively. The inclusion criteria were as follows: age over 18 years, having cerebral infarction or transient ischemic stroke, and having 24-hour Holter ECG examination data. The exclusion criteria were as follows: the presence of chronic AF, carotid stenosis over $70 \%$ on the symptomatic side, lacunar infarctions and small vessel disease, or the presence of other conditions (e.g. arthritis, dissection) that could explain the etiology of stroke.

Demographic data, clinical data, comorbid diseases, cranial computed tomography, cranial magnetic resonance imaging (MRI), bilateral carotid and vertebral artery Doppler ultrasonography, ECG and transthoracic echocardiography findings were recorded. The total STAF score used in predicting PAF was between 0 and 8 , and the specificity and sensitivity of values above 5 were found to be higher (Table 1) (10). Atrial dilatation evaluated in the STAF score and left ventricular hypertrophy (LVH) were evaluated in the study because they caused AF. The vascular etiologies included in the STAF score was the presence of stenosis in the extracranial arteries over $50 \%$, dissection, and lacunar infarction. The CHA2DS2-VASc is used to determine the risk of thromboembolism in patients with AF. The total score that can be obtained in CHA2DS2-VASc is in the range of 0-9 and scores are evaluated as follows: congestive heart failure (CHF): 1 point, hypertension (HT): 1 point, age $\geq 75$ years: 2 points, diabetes mellitus (DM): 1 point, stroke or transient ischemic attack (TIA): 2 points, vascular disease: 1 point, age 65-74 years: 1 point, female sex: 1 point (11). With this evaluation, the CHA2DS2-VASc scores of the patients were calculated. NIHSS scores were calculated according to the first neurologic examinations. The NIHSS is the neurologic examination scale of patients with stroke. It consists of 15 items with a minimum of 0 points and a maximum of 42 points (12). According to the examinations at discharge, mRS was calculated (13). $\mathrm{mRS}$ is a 6-item scale measuring the disability status of a patient with stroke, with a minimum score of 0 and a maximum score of 6 .

\section{Statistical Analysis}

The IBM SPSS Statistics Version 20.0 package program was used in the analysis of the data. Categorical measurements are presented as numbers and percentages. Numerical measurements as mean and standard deviation (median and minimum-maximum where necessary) and descriptive statistical methods were used.

\begin{tabular}{|lc|}
\hline \multicolumn{2}{|c|}{ Table 1. Criteria and scoring used in the STAF score } \\
\hline \multicolumn{2}{|c|}{ Score } \\
Age & \\
$>62$ & 2 \\
$\leq 62$ & 0 \\
NIHSS & \\
$\geq 8$ & 1 \\
$<8$ & 0 \\
Left atrial dilatation & \\
Yes & 1 \\
No & 0 \\
Vascular etiology & \\
Yes & 0 \\
No & 3 \\
Total score & $0-8$ \\
${ }^{\circ}$ Taken from reference 10, NIHSS: National Institutes of Health Stroke Scale \\
Score, STAF: Score for the targeting of atrial fibrillation \\
\hline
\end{tabular}


While analyzing the relationship between variables, Pearson correlation analysis was used for data with normal distribution, and Spearman correlation analysis was used for data that did not show normal distribution. Logistic regression analysis was used to evaluate the factors associated with PAF detection. Independent sample t-test was used for comparisons between groups. The statistical significance level was accepted as 0.05 in all tests.

\section{Results}

The mean age of the 98 patients participating in our study was $64.4 \pm 14.1$ years. Of the patients included in the study, $50 \%$ $(\mathrm{n}=49)$ were in the PAF group and $50 \%(\mathrm{n}=49)$ were in the group without PAF. The mean age was $66.98 \pm 11.9$ years in the group with PAF and 59.84 \pm 15.23 in the group without PAF (Figure 1). There was a statistically significant difference between groups in terms of age $(\mathrm{p}=0.01)$. Twenty-five those with PAF were female and 24 were male, and 24 of those without PAF were female and 25 were male. There was no difference between groups in terms of sex $(\mathrm{p}=0.8)$. There were no significant differences between the groups in terms of CHF ( $\mathrm{p}=0.64), \mathrm{DM}(\mathrm{p}=0.52), \mathrm{HT}(\mathrm{p}=0.19)$, and vascular disease $(\mathrm{p}=0.87)$. When the CHA2DS2-VASc score was compared between the groups, there was no statistically significant difference (PAF detected: $4.69 \pm 1.45$, no PAF detected: $4.20 \pm 1.77$, $\mathrm{p}=0.14)$. No significant difference was found between the groups in terms of left atrial dilatation, $\mathrm{LVH}$, mitral insufficiency, and STAF score (Table 2).

According to the location, $73.5 \%(n=36)$ of the patients with PAF had supratentorial, and $26.5 \%(n=13)$ had infratententorial infarctions. Of the patients with no PAF, 67.3\% $(n=33)$ had supratentorial, and $32.7 \%(n=16)$ had infratentorial infarctions $(\mathrm{p}=0.50)$.

There was no significant difference in terms of the rate of recurrent stroke between the groups $(p=0.34)$. NIHSS score $(\mathrm{p}=0.94)$ and $\mathrm{mRS}(\mathrm{p}=0.16)$ did not differ significantly between the groups with and without PAF (Table 3).

In the logistic regression analysis, the relationship between PAF detection and age, sex, CHF, DM, HT, presence of known vascular disease, CHA2DS2-VASc score, left atrial dilatation, LVH, mitral insufficiency, and STAF score were evaluated. Among these, the most associated factor with PAF detection was advanced age $(p=0.01$ and $\beta=0.960)$. No significant relationship was found between PAF detection and STAF score, left atrial dilatation, LVH, mitral insufficiency, and PAF in logistic regression analysis $(\mathrm{p}>0.05)($ Table 4$)$.

\section{Discussion}

This study was planned to determine the effect of demographic and clinical data, STAF score, and CHA2DS2-VASc score on the probability of detecting PAF in patients with CIS. Thus, it was

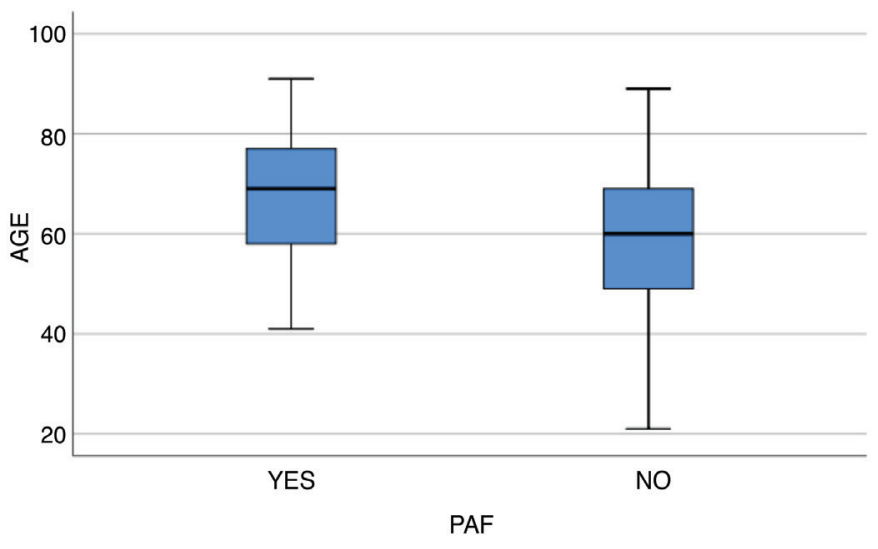

Figure 1. Age distribution of patients with and without PAF PAF: Paroxysmal atrial fibrillation

Table 2. Comparative table of STAF score, demographic and clinical data between groups

\begin{tabular}{|c|c|c|c|}
\hline & $\operatorname{PAF}(+)$ & PAF (-) & $\mathrm{p}$ value \\
\hline \multirow[t]{2}{*}{ Age (years \pm SD) } & $66.98 \pm 11.9$ & $59.84 \pm 15.23$ & 0.01 \\
\hline & (n) $\%$ & (n) $\%$ & \\
\hline Female/male & $51(25) / 49(24)$ & $49(24) / 51(25)$ & 0.84 \\
\hline $\mathrm{CHF}$ & $6.1 \%(3)$ & $4.1 \%(2)$ & 0.64 \\
\hline $\mathrm{DM}$ & $30.6 \%(15)$ & $36.7 \%(18)$ & 0.52 \\
\hline HT & $73.5 \%(36)$ & $61.2 \%(30)$ & 0.19 \\
\hline Vascular disease & $\begin{array}{l}26.5 \%(13) \\
\text { (CAD: 11, PAD: 1, VST: } 1)\end{array}$ & $\begin{array}{l}24.4 \% \text { (12) } \\
\text { (CAD: 9, PAD: 1, VST: 1) }\end{array}$ & 0.87 \\
\hline CHA2DS2-VASc score & $4.69 \pm 1.45$ & $4.20 \pm 1.77$ & 0.14 \\
\hline Left atrial dilatation & $4 \%(2)$ & $6 \%(3)$ & 0.65 \\
\hline Left ventricular hypertrophy & $16 \%(8)$ & $32 \%(16)$ & 0.56 \\
\hline Mitral insufficiency & $30 \%(15)$ & $27 \%(13)$ & 0.66 \\
\hline STAF score & 3.16 & 3.18 & 0.95 \\
\hline $\begin{array}{l}\text { STAF score } \\
\geq 5 \\
<5\end{array}$ & $\begin{array}{l}43 \%(21) \\
57 \%(28)\end{array}$ & $\begin{array}{l}27 \%(13) \\
73 \%(36)\end{array}$ & 0.09 \\
\hline
\end{tabular}


Table 3. Comparative table of NIHSS, mRS, and recurrent stroke rate between groups

\begin{tabular}{llll} 
& PAF $(+)$ & PAF (-) & p value \\
NIHSS (mean \pm SD) & $4.40 \pm 3.10$ & $3.59 \pm 2.59$ & 0.94 \\
mRS (mean \pm SD) & $2.06 \pm 1.3$ & $2.04 \pm 1.1$ & 0.16 \\
Recurrent stroke $(n) \%$ & $28.6 \%(14)$ & $20.4 \%(10)$ & 0.34 \\
NIHSS: National Institutes of Health Stroke Scale Score, mRS: Modified Rankin scale, PAF: Paroxysmal atrial fibrillation, SD: Standard deviation \\
\hline
\end{tabular}

\begin{tabular}{|lll|}
\hline \multicolumn{3}{|l|}{ Table 4. Logistic regression analysis: comparison of PAF } \\
with demographic and clinical data \\
Age & p value & $\beta$ value \\
Sex & 0.14 & 0.039 \\
CHF & 0.84 & 0.082 \\
DM & 0.89 & 0.135 \\
HT & 0.33 & -0.449 \\
Vascular disease & 0.21 & 0.569 \\
Left atrial dilatation & 0.76 & 0.064 \\
Left ventricular hypertrophy & 0.57 & -0.359 \\
Mitral insufficiency & 0.64 & 0.332 \\
STAF score & 0.95 & 0.210 \\
CHA2DS2-VASc score & 0.13 & 0.007 \\
PAF: Paroxysmal atrial fibrillation, CHF: Congestive heart failure, DM: Diabetes \\
mellitus, HT: Hypertension, STAF: Score for the targeting of atrial fibrillation
\end{tabular}

aimed to emphasize in which patient group 24-hour Holter ECG recording should be performed in order to investigate etiology. In our study, it was found that the most effective factor in the detection of PAF was advanced age.

In a prospective study conducted in Norway, 24-hour Holter ECG was performed on 1,239 of 3,480 patients who had TIA or ischemic stroke between 2006-2015; PAF was found in 237 $(19 \%)$ and sinus rhythm was found in 1,002 (81\%). When the demographic and clinical data of the two groups were compared, increased age, female sex, previous ischemic stroke, myocardial infarction, pathologic troponin levels, embolic stroke, and infarcts in different arterial areas were found to be important predictors of PAF $(\mathrm{p}<0.01)$ (14). In our study, PAF was found in 49 of 310 patients with stroke. However, Holter ECG could not be performed on all of our patients, so our PAF rate was found to be high. In our study, the relationship between advanced age and PAF was found to be significant, but unlike the Norwegian study, no significant relationship was found between PAF detection and sex, prior stroke, arterial diseases, and lesion location. The reason for this difference could be that the Norwegian study was conducted over a longer period and with more patients.

In a study in which 227 patients with stroke were included, PAF was detected in $13.6 \%(n=31)$ of patients using 28-day Holter ECG recording and patients with and without PAF were compared in terms of demographic, radiographic, and clinical data. In that study, it was reported that age $(\mathrm{p}=0.005)$ and the presence of previous stroke findings on radiologic imaging $(\mathrm{p}=0.021)$ were determinants of AF detection (15). In our study, it was found that although age was related to AF detection, previous stroke was not related to AF detection. Unlike that study, the Holter ECGs of our patients were recorded for 24 hours and could not be performed in all patients with stroke.

In a study investigating the reliability of STAF scores (2009), 486 patients with stroke were included, and it was found that 122 (26.7\%) patients had AF, including 86 patients with AF in the initial ECGs. When the demographic and clinical data of patients with and without AF were compared, they found that advanced age, female sex, HT, NIHSS, left atrial dilatation, LVH, and left mitral insufficiency were highly correlated with AF detection (16). In another study (2013) with a similar design, 183 (31.3\%) of 584 patients with stroke were found to have AF, and they reported that age, NIHSS, left atrial dilatation, and absence of vascular etiology were superior to the STAF score as independent markers in predicting AF (17). In another study (2018) evaluating the reliability of STAF scores, PAF was found in 30 (22.6\%) of 133 patients with cryptogenic stroke. It was determined that the use of STAF scores to detect AF in patients with stroke had limitations, but age and sex could be used as independent indicators $(\mathrm{p}<0.01)$ (6). In our study, the strongest correlation was found between advanced age and the prediction of PAF $(\mathrm{p}<0.01)$. In our study, the relationship between $\mathrm{CHF}, \mathrm{DM}, \mathrm{HT}$, presence of vascular disease, recurrent stroke, CHA2DS2-VASc score, left atrial dilatation, LVH, mitral insufficiency, STAF score, NIHSS, mRS, and PAF detection was not found significant $(\mathrm{p}>0.05)$. The reason why our data differed from the literature was that only patients with paroxysmal AF were included in the study, the number of patients was low, and our study period was short.

In our study, a comparison was made between groups by only looking at the supra-tentorial and infra-tentorial location of the infarct in MRI and no significant relationship was found. In the CRYSTAL AF study, which examined the infarct topography in more detail, it was reported that the location of the lesion, the involved vessel area, and the size of the infarct could not be used to predict AF (18).

\section{Study of Limitations}

The study was arranged retrospectively. Holter ECG was performed on 98 of the 310 patients because some of our patients did not come to the Holter ECG even though they were called. Holter ECG recordings were planned once for 24 hours and were not repeated.

\section{Conclusion}

As a result, 24-hour or even longer Holter ECG recording is required to search for PAF in CIS in the elderly population.

\section{Acknowledgements}

I would like to thank my prelectors for their knowledge and support during and after the residency training. 


\section{Ethics}

Ethics Committee Approval: This study was approved by the Taksim Research and Training Hospital Ethics Committee (number: 102, date: 21.08.2019).

Informed Consent: Written or verbal consent was not obtained from the patients because the study was conducted retrospectively.

Peer-review: Externally peer-reviewed.

\section{Authorship Contributions}

Surgical and Medical Practices: A.T.P., Z.M.G., Y.Ş., Concept: A.T.P., Design: A.T.P., Data Collection or Processing: A.T.P., Z.M.G., Y.Ş., Literature Search: A.T.P., Z.M.G., Y.Ş., Writing: A.T.P., Y.Ş.

Conflict of Interest: No conflict of interest was declared by the authors.

Financial Disclosure: The authors declared that this study received no financial support.

\section{References}

1. Hart RG, Diener HC, Coutts SB, et al. Embolic strokes of undetermined source: the case for a new clinical construct. Lancet Neurol 2014;13:429438.

2. Alexandru R, Terecoasa EO, Bajenaru OA, Tiu C. Etiologic classification of ischemic stroke: where do we stand? Clin Neurol Neurosurg 2017;159:93106.

3. Schulz UG. Cryptogenic stroke - How to make sense of a non-diagnostic entity. Maturitas 2019;122:44-50.

4. Banerjee A, Marín F, Lip GYH. A new landscape for stroke prevention in atrial fibrillation: focus on new anticoagulants, antiarrhythmic drugs, and devices. Stroke 2011;42:3316-3322.

5. Flint AC, Banki NM, Ren X, Rao VA, Go AS. Detection of paroxysmal atrial fibrillation by 30-day event monitoring in cryptogenic ischemic stroke: the Stroke and Monitoring for PAF in Real Time (SMART) Registry. Stroke 2012; $43: 2788-2790$
6. Rizos T, Güntner J, Jenetzky E, et al. Continuous stroke unit electrocardiographic monitoring versus 24-hour Holter electrocardiography for detection of paroxysmal atrial fibrillation after stroke. Stroke 2012;43:2689-2694.

7. Levy S, Novella P, Ricard P, Paganelli F. Paroxysmal A trial fibrillation: a need for classification. J Cardiovasc Electr 1995;6:69-74.

8. Furie KL, Kasner SE, Adams RJ, et al. Guidelines for the prevention of stroke in patients with stroke or transient ischemic attack: a guideline for healthcare professionals from the American Heart Association/American Stroke Association. Stroke 2011;42:227-276

9. Suissa L, Bertora D, Lachaud S, Mahagne MH. Score for the targeting of atrial fibrillation (STAF): a new approach to the detection of atrial fibrillation in the secondary prevention of ischemic stroke. Stroke 2009;40:2866-2868.

10. Göksu EÖ, Yüksel B, Esin M, et al. The value of STAF (Score for the Targeting of Atrial Fibrillation) in Patients with Cryptogenic Embolic Stroke. Arch Neuropsychiatry 2019;56:119-122.

11. Kirchhof P, Benussi S, Kotecha D, et al. 2016 ESC Guidelines forthe management of atriyal fibrillation developed in collaboration with EACTS Europace 2016;18:1609-1678.

12. Brott T, Adams Jr HP, Olinger CP, et al. Measurements of acute cerebral infarction: a clinical examination scale. Stroke 1989;20:864-870.

13. Quinn TJ, Dawson J, Walters M. Dr John Rankin; his life, legacy and the 50th anniversary of the Rankin stroke scale. Scot Med J 2008;53:44-47.

14. Naess H, Andreassen UW, Thomassen L, Kvistad CE. A score for paroxysmal atrial fibrillation in acute ischemic stroke. Int J Stroke 2018;13:496-502.

15. Favilla CG, Ingala E, Jara J, et al. Predictors of finding occult atrial fibrillation after cryptogenic stroke. Stroke 2015;46:1210-1215.

16. Suissa L, Bertora D, Lachaud S, Mahagne MH. Score for the targeting of atrial fibrillation (STAF) a New approach to the detection of atrial fibrillation in the secondary prevention of ischemic stroke. Stroke 2009;40:2866-2868.

17. Horstmann S, Rizos T, Güntner J, et al. Does the STAF score help detect paroxysmal atrial fibrillation in acute stroke patients? Eur J Neurol 2013;20:147-152.

18. Bernstein RA, Di Lazzaro V, Rymer MM, et al. Infarct topography and detection of atrial fibrillation in cryptogenic stroke: results from CRYSTAL AF. Cerebrovasc Dis 2015;40:91-96. 